\title{
Ventilation Response During Physical Testing in Patients with Chronic Heart Failure and Chronic Obstructive Pulmonary Disease
}

\author{
Kira Ageeva*, Vladimir Abrosimov and Lyudmila Khasanova \\ Department of Infection Disease, Russia \\ *Corresponding author: Kira Ageeva, Department of Infection Disease, Russia
}

\section{ARTICLE INFO}

Received: 幽 July 20, 2019

Published: 蔧 July 30, 2019

Citation: Kira Ageeva, Vladimir Abrosimov, Lyudmila Khasanova. Ventilation Response During Physical Testing in Patients with Chronic Heart Failure and Chronic Obstructive Pulmonary Disease. Biomed J Sci \& Tech Res 20(1)2019. BJSTR. MS.ID.003406.

\begin{abstract}
Patients with $\mathrm{CHF}$ and COPD were examined during physical activity with dynamic monitoring of $\mathrm{CO}_{2}$. Parameters of dyspnea are compared with $\mathrm{CO}_{2}$ values before, during and after 6MWT. When performing physical activity revealed signs of periodic breathing, which has a prognostic value.
\end{abstract}

\section{Introduction}

Dyspnea is the most important symptom of patients with Chronic Heart Failure (CHF) and patients with Chronic Obstructive Pulmonary Disease (COPD). The nature of this dyspnea, despite tremendous advances in the fields of cardiology and pulmonology, is not well known [1,2]. Difficulties arise probably when trying to objectify the patient's subjective feelings. This is partly due to the lack of a unified interpretation of the concept of dyspnea. Necessary measures in the diagnosis are methods of instrumental objectivization $[3,4]$. Along with the generally accepted methods of examination, various functional diagnostic methods are used to determine functional impairment, in which the parameters of gas exchange are often examined [5]. The value of end-tidal $\mathrm{CO}_{2}\left(\mathrm{P}_{\mathrm{ET}} \mathrm{CO}_{2}\right)$ is a constant that indicates the activity of the respiratory system [6]. Dyspnea is combined with changes in pulmonary ventilation and $\mathrm{CO}_{2}$ gas exchange $[7,8]$. Dyspnea is one of the most frequent reasons why patients stopped during the 6-Minute Walk Test (6MWT). Exercise tests are used to determine exercise tolerance in patients with CHF and COPD [9].

\section{Purpose}

To explore the features of changes $\mathrm{P}_{\mathrm{ET}} \mathrm{CO}_{2}$ during execution 6MWT in patients with CHF and COPD.

\section{Methods}

We studied 52 patients with CHF in New York Heart Association (NYHA), age $58 \pm 3,24$ years (25 patients $(48,1 \%$ ) in NYHA class II, 22 patients $(4,3 \%)$ in NYHA class III, 5 patients $(9,6 \%)$ in NYHA class IV). Also, we studied 42 patients with COPD II-III, age $60 \pm 3,48$ years $\left(1^{\text {st }}\right.$ group - 22 patients $(52,4 \%)$ with COPD II, $2^{\text {nd }}$ group-20 patients $(47,6 \%)$ with COPD III). Control group 30 patients, age $48 \pm 3,42$ years. Standard 6MWT was performed. Dyspnea was evaluated on a scale of Borg, MRS and VAS. We recorded nanogram before, during, after the 6MWT and in the recovery period using a capnograph Life Sense.

\section{Results}

Significance of $\mathrm{P}_{\mathrm{ET}} \mathrm{CO}_{2}$ in patients with CHF in NYHA class II was $38,2 \pm 2,13 \mathrm{~mm} \mathrm{Hg}$, in patients in NYHA class III was $34,4 \pm 2,22 \mathrm{~mm}$ $\mathrm{Hg}$, in patients in NYHA class IV was $32,4 \pm 1,14 \mathrm{~mm} \mathrm{Hg}$. Significance of $\mathrm{P}_{\mathrm{ET}} \mathrm{CO}_{2}$ in $1^{\text {st }}$ group patients with COPD was $36,2 \pm 2,43 \mathrm{~mm} \mathrm{Hg}$, in $2^{\text {nd }}$ group patients was $34,1 \pm 1,22 \mathrm{~mm} \mathrm{Hg}$. All patients performed 6MWT. The 6MWT distance in patients with CHF in NYHA class II was $384 \pm 10,56 \mathrm{~m}$, in NYHA class III was $290 \pm 17,24 \mathrm{~m}$, in NYHA class IV was $142 \pm 3,51 \mathrm{~m}$. The $6 \mathrm{MWT}$ distance in $1^{\text {st }}$ group patients with 
COPD was $440 \pm 15,48 \mathrm{~m}$, in $2^{\text {nd }}$ group was $384 \pm 15,42 \mathrm{~m}$. There is reduction $\mathrm{P}_{\mathrm{ET}} \mathrm{CO}_{2}$ in all patients with $\mathrm{CHF}$ during the 6MWT. $\mathrm{P}_{\mathrm{ET}} \mathrm{CO}_{2}$ in patients with CHF in NYHA class II was $33,34 \pm 2,51 \mathrm{~mm} \mathrm{Hg}$, in NYHA class III was $31,75 \pm 2,89 \mathrm{~mm} \mathrm{Hg}$, in NYHA class IV was $28,8 \pm 1,32 \mathrm{~mm}$ Hg. $69,2 \%$ patients reported dyspnea as the main reason for a stop during the 6MWT. There is increase $\mathrm{P}_{\mathrm{ET}} \mathrm{CO}_{2}$ in all patients with COPD during the 6MWT. After the 6MWT the significance of $\mathrm{P}_{\mathrm{ET}} \mathrm{CO}_{2}$ in $1^{\text {st }}$ group was $43,21 \pm 2,81 \mathrm{~mm} \mathrm{Hg}$, in $2^{\text {nd }}$ group was $45,05 \pm 3,26$ $\mathrm{mm} \mathrm{Hg}$. All patients reported dyspnea as the main reason for a stop during the execution 6MWT. When we analyzed the trend of $\mathrm{P}_{\mathrm{ET}} \mathrm{CO}_{2}$ we found that these patients showed signs of periodic breathing (Figure 1) than control group.

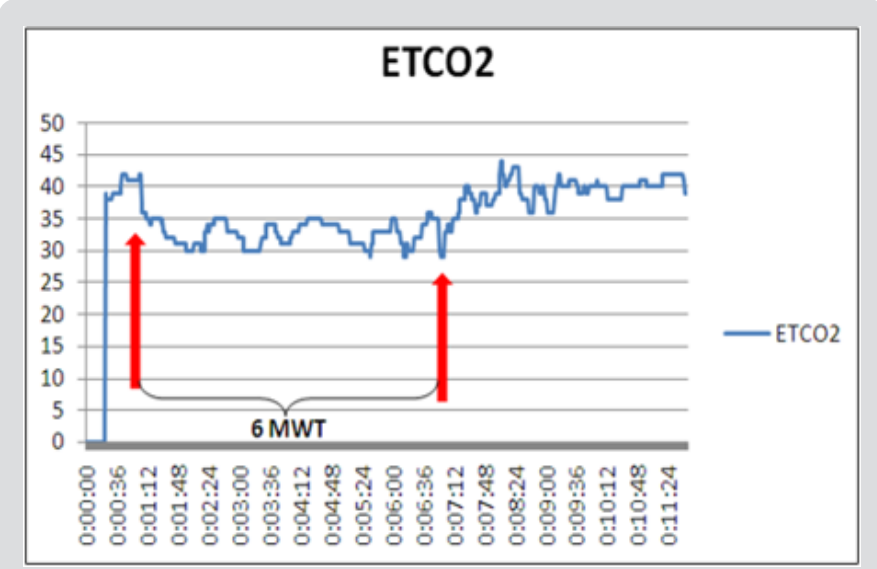

Figure 1: Trend $\mathrm{P}_{\mathrm{ET}} \mathrm{CO}_{2}$ in patient with CHF II NYHA.

\section{Conclusion}

Thus, capnography increases the diagnostic value of the 6MWT, helps to make interpretation of dyspnea in patients with CHF and COPD.

\section{ISSN: 2574-1241}

DOI: 10.26717/BJSTR.2019.20.003406

Kira Ageeva. Biomed J Sci \& Tech Res



This work is licensed under Creative Commons Attribution 4.0 License

Submission Link: https://biomedres.us/submit-manuscript.php

\section{References}

1. Garcia Aymerich J, Serra I, Gómez FP, Farrero E, Balcells E, et al. (2009) Physical activity and clinical and functional status in COPD. Chest 136(1): 62-70.

2. Garcia Rio F, Lores V, Mediano O, Rojo B, Hernanz A, et al. (2009) Daily physical activity in patients with chronic obstructive pulmonary disease is mainly associated with dynamic hyperinflation. Am J Respir Crit Care Med 180(6): 506-512.

3. Pitta F, Takaki MY, Oliveira NH, Santanna TJ, Fontana AD, et al. (2008) Relationship between pulmonary function and physical activity in daily life in patients with COPD. Respir Med 102(8): 1203-1207.

4. Eliason G, Zakrisson AB, Piehl Aulin K, Hurtig Wennlöf A (2011) Physical activity patterns in patients in different stages of chronic obstructive pulmonary disease. COPD 8(5): 369-374.

5. Francis DP, Shamim W, Davies LC, Piepoli MF, Ponikowski P, et al. (2000) Cardiopulmonary exercise testing for prognosis in chronic heart failure: Continuous and independent prognostic value from VE/VCO(2) slope and peak VO(2). Eur Heart J 21(2): 154-161.

6. LL SHika, NN Kanaeva (1980) General issues of research methods and criteria for assessing respiratory rates. Medicine 21-36.

7. Csorba Z, Petak F, Nevery K, Tolnai J, Balogh AL, Rarosi F, et al. (2016) Capnographic parameters in ventilated patients: Correspondence with airway and lung tissue mechanics. Anesthesia and Analgesia 122(5): $1412-1420$

8. P Messner Pellenc, C Brasileiro, S Ahmaidi, J Mercier, C Ximenes, et al. (1995) Exercise intolerance in patients with chronic heart failure: Role of pulmonary diffusing limitation. Eur Heart J 16(2): 201-209.

9. Belza B, Steele BG, Hunziker J, Lakshminaryan S, Holt L, et al. (2001) Correlates of physical activity in chronic obstructive pulmonary disease. Nurs Res 50(4): 195-202.



